\title{
Kiai dan Politik Elektoral: Peran Kiai Yusuf Chudlori dalam Pemenangan Kandidat Jokowi-Ma'ruf Amin pada Pilpres 2019 di Kecamatan Tegalrejo
}

Rizky Amalia Aziz ${ }^{1}$

\begin{abstract}
Abstrak
Peran kiai dalam pemenangan kandidat pemilu menjadi efektif karena ia berperan di dua level, yaitu sebagai konsolidator kekuatan politik di level elit dan sebagai mobilisator suara pemilih di level grassroot. Tulisan ini membahas peran Kiai Yusuf Chudlori sebagai konsolidator jaringan kiai dan mobilisator suara pemilih dalam pemenangan kandidat JokowiMa'ruf pada pilpres 2019 di Kecamatan Tegalrejo. Metode kualitatif dengan pendekatan studi kasus digunakan untuk mengkaji permasalahan ini. Data dikumpulkan dengan metode wawancara mendalam, observasi partisipatoris, dan dokumentasi. Kajian ini menunjukkan bahwa Gus Yusuf berhasil mengonsolidasikan jaringan kiai secara gradual sehingga terbentuk kekuatan politik yang stabil. Jaringan kiai ini berfungsi untuk menjangkau massa jamaah secara luas. Di sisi lain, sebagai kiai yang paling berpengaruh secara elektoral di Tegalrejo, Gus Yusuf berperan efektif sebagai mobilisator suara pemilih karena banyaknya pengajian sebagai sarana mobilisasi, kuatnya pengaruh Gus Yusuf dalam kehidupan masyarakat, serta penggunaan metode-metode mobilisasi yang menarik. Tulisan ini menyimpulkan bahwa pemenangan kandidat Jokowi-Ma'ruf di Tegalrejo menjadi efektif karena Gus Yusuf berperan kolaboratif sebagai konsolidator yang bergerak di level elit dan mobilisator yang bergerak di level akar rumput.
\end{abstract}

Kata kunci: Peran Kiai; Politik Elektoral; Konsolidator; Mobilisator

1 Alumni Departemen Politik dan Pemerintahan, Fakultas Ilmu Sosial dan Ilmu Politik, Universitas Gadjah Mada. Email: rizky.amalia.a@mail.ugm.ac.id 


\section{PENDAHULUAN}

Kajian ini membahas peran Kiai Yusuf Chudlori dalam pemenangan kandidat Jokowi-Ma'ruf pada pilpres 2019 di Kecamatan Tegalrejo, Kabupaten Magelang. Selama ini, kiai dikenal akan efektivitasnya dalam memobilisasi massa (Geertz, 1960; Bruinessen, 1999; Nurhadi dan Sunarso, 2018). Tetapi sesungguhnya, kiai tidak bekerja sendiri dalam memenangkan kandidat yang ia dukung. Secara umum, ia memiliki koalisi atau kelompok sesama kiai yang biasa berkonsolidasi untuk membentuk kekuatan politik pada masa kampanye (Chalik, 2016; Hidayat, 2016). Fokus kajian ini melihat pada peran Gus Yusuf sebagai konsolidator jaringan kiai dan mobilisator suara pemilih. Sebagai pembahasan lebih lanjut, tulisan ini juga menganalisis bagaimana koneksi yang terbangun dalam lingkaran politik Jokowi berimplikasi terhadap kesepakatan bisnis.

Peran Gus Yusuf dalam politik elektoral yang melibatkan eksistensi NU maupun PKB menjadi relevan karena ia merupakan tulang punggung pemenangan Jokowi-Ma'ruf di Jawa Tengah (kumparannews, 2019). Permasalahan ini menarik karena berkaitan dengan klaim dari kalangan NU maupun PKB bahwa melalui merekalah Jokowi dapat mendongkrak suaranya dibandingkan pilpres 2014. Walaupun Gus Yusuf 
bertanggungjawab terhadap konsolidasi suara di level provinsi, namun Tegalrejo merupakan lokasi penelitian yang penting untuk menampilkan pengaruh elektoral kiai di basisnya. Kecamatan ini merupakan poros pengaruh terkuat di Jawa Tengah (Arifin, 2008) karena keberadaan pesantren milik keluarga Chudlori, yaitu Asrama Perguruan Islam (API).

Asrama Perguruan Islam (API) yang tidak lain juga pesantren tempat Gus Dur belajar agama merupakan tempat bersejarah bagi proses lahirnya PKB. Pertama kalinya, kiai se-Jawa yang berjumlah kurang-lebih 1.500 mengadakan pertemuan di API pada awal Reformasi. Pertemuan tersebut berbuah kesepakatan bahwa NU harus mendirikan partai. Kesepakatan inilah yang menjadi cikal bakal lahirnya PKB. Selain itu, Rembang sebagai poros PPP secara elektoral masih kalah jauh dengan PKB yang menempati posisi kedua di kursi legislatif Jateng, baik di periode 2014 maupun 2019. Oleh sebab itu, kecamatan ini merupakan lokasi penelitian yang tepat untuk melihat kontestasi pemilu yang melibatkan kekuatan NU dan PKB.

Pada pilpres 2019, Gus Yusuf berperan sebagai konsolidator jaringan kiai NU dan mobilisator suara pemilih di lingkungan Tegalrejo. Gus Yusuf secara gradual berhasil mengonsolidasikan jaringan kiai yang 
tergabung dalam Majelis Wakil Cabang (MWC) NU Tegalrejo atau NU tingkat kecamatan sebagai kekuatan elektoral PKB. Jaringan inilah yang digunakan Gus Yusuf untuk menjangkau massa jamaah secara luas. Di sisi lain, sebagai kiai yang paling berpengaruh secara elektoral di kecamatan ini, Gus Yusuf berperan efektif sebagai mobilisator suara pemilih karena banyaknya pengajian sebagai sarana mobilisasi dan kuatnya pengaruh Gus Yusuf serta Pesantren API dalam kehidupan masyarakat. Tidak mengherankan jika di Tegalrejo suara Jokowi meningkat dari 18.847 ke 24.768, sedangkan suara Prabowo menurun dari 13.883 ke 9.712 dibandingkan pilpres 2014 (KPU RI, 2019). Jokowi-Ma'ruf juga memperoleh kemenangan di semua desa (21 desa) di Tegalrejo sedangkan pada pilpres sebelumnya menang di 17 desa (KPU RI, 2019). Oleh sebab itu, pemenangan kandidat Jokowi-Ma'ruf di Tegalrejo menjadi efektif karena Gus Yusuf berperan kolaboratif sebagai konsolidator yang bergerak di level elit dan mobilisator yang bergerak di level akar rumput. Argumen inilah yang digunakan dalam menguraikan peran Gus Yusuf pada pemenangan paslon 01 di Tegalrejo.

Kajian ini menggunakan metode kualitatif dengan pendekatan studi kasus. Kasus dibatasi dengan melihat 
peran Gus Yusuf selama masa kampanye pilpres 2019 di Kecamatan Tegalrejo. Data kualitatif dikumpulkan dengan metode wawancara mendalam, observasi partisipatoris, dan dokumentasi. Pengumpulan data primer dimulai sekitar bulan Maret 2019 dan diakhiri pada bulan Desember 2019. Data sekunder digali dan didapat sebelum penelitian lapangan hingga penulisan melalui sumber online mupun offline seperti buku, jurnal, tesis, berita, youtube, dan data resmi pemerintah.

\section{KAJIAN LITERATUR}

Studi tentang keterlibatan kiai dalam politik elektoral semakin berkembang pasca Reformasi seiring dengan masifnya keterlibatan kiai dalam politik, setelah sebelumnya fokus pada kelembagaan NU. Kajian Patoni (2007) menggambarkan maraknya fenomena transformasi peran kiai dari tugas pokoknya sebagai pembina pesantren menjadi seorang aktor, pendukung, dan partisipan dalam partai politik. Sejak kran partisipasi politik terbuka lebar, banyak kiai mulai melibatkan diri secara langsung dalam partai politik yang membuat perannya di pesantren semakin terbengkalai. Meskipun begitu, kiai tidak kehilangan kepercayaan dari masyarakat santri karena ada kesepahaman bahwa tindakan kiai didasari oleh motif 
untuk memperjuangkan agama melalui jalur struktural sekaligus menegakkan moralitas politik. Namun pada praktiknya, cita-cita tersebut bukanlah perkara yang mudah untuk realisasikan.

Studi kasus di Kebumen menunjukkan bahwa upaya kiai untuk mewujudkan moralitas politik berupa clean governance ternyata kontraproduktif dengan pembangunan ekonomi dan pelayanan publik. Proyek-proyek besar mengalami penurunan aktivitas dikarenakan kehati-hatian pemerintah dalam mengurusi perijinan. Kepemimpinan religius yang mengutamakan pembangunan akhlak ternyata tidak berbanding lurus dengan urusan duniawi dalam menghasilkan efektivitas kebijakan publik (Alfirdaus, 2013). Hal ini kembali menguatkan pendapat Geertz (1960) bahwa posisi kiai kuat sebagai vote getter akan tetapi lemah di sisi bargaining power kebijakan.

Meskipun begitu, motivasi kiai untuk mewujudkan kebijakan yang berpihak pada kepentingan umatnya tidak pernah surut. Kiai seringkali menunjukkan sikap inkonsistensi dukungan, tergantung pada kubu mana yang sekiranya mampu menjamin kepentingan umat yang menjadi prioritasnya. Sikap tersebut membuat kiai atau NU dicap sebagai pihak yang oportunis, pragmatis, dan inkonsisten di kancah politik. Dari sudut pandang 
sebaliknya, hal tersebut justru merupakan bentuk konsistensi kiai dalam mengedepankan kepentingan dan kemaslahatan umat (Febrina, Mustika, Dedees, 2014).

Bukan tanpa tantangan, terjunnya kiai ke ranah politik yang diikuti oleh stigma oportunis berdampak negatif bagi pengaruh kiai. Delegitimasi peran pesantren sebagai otoritas moral dan pendidikan disebabkan karena kiai politisi cenderung tidak memiliki banyak waktu untuk mengurusi pendidikan santrinya. Independensi pesantren sebagai penjaga moral juga semakin sulit ditegakkan ketika kiainya masuk dalam lingkaran kekuasaan dan secara tidak sadar tunduk pada kekuatan tersebut. Selain itu, muncul sikap resistensi masyarakat terhadap sikap politik pesantren jika kiainya terlalu mengedepankan kepentingan politik yang tidak berkaitan dengan kepentingan agama (Ernas, Siregar, 2010).

Reduksi karisma kiai merupakan dampak negatif yang paling merugikan bagi sosok yang dianggap sebagai simbol kesucian dan keberkahan tersebut. Studi dari Hosnan (2019) berupaya mengungkap fenomena reduksi karisma kiai dalam percaturan politik lokal di Madura. Kiai yang semula merupakan elit agama berpengaruh lama-kelamaan ditinggalkan oleh pengikutnya karena ia terlibat dalam pusaran politik uang. Reduksi 
karisma ditandai dengan pandangan masyarakat yang menganggap bahwa kiai tidak berbeda dengan politisi biasa karena tidak melandasi tindakannya dengan ajaran agama Islam.

Penurunan dukungan masyarakat terhadap sikap politik kiai merupakan dampak lebih lanjut dari berbagai fenomena tersebut. Hasil penelitian Hosnan (2019) mengungkapkan bahwa kekalahan kiai dalam beberapa kontestasi kekuasaan bahkan terjadi di daerah basis pesantren, seperti Madura. Para kiai berusaha membenarkan perilaku politik uang dengan landasan teks-teks dalam kitab suci. Praktik politik uang oleh kubu kiai bukannya berhasil meraup dukungan masyarakat, namun justru memunculkan distrust pada kiai tersebut. Terbukti bahwa kiai dan keluarganya yang sudah tidak dipercaya masyarakat gagal meraih kursi legislatif pada pemilu 2009 dan 2014. Selain itu, muncul semboyan "Bupati Asal Bukan Kiai” menjelang pilkada serentak 2020 menunjukkan adanya puncak kekecewaan masyarakat terhadap permainan politik kiai yang semakin kotor (Hosnan, 2019).

Berbeda dengan pendapat Hosnan, penurunan dukungan santri terhadap sikap politik kiai disebabkan karena perubahan sistem relasi patron-client antara kiai dan masyarakat santri (Masruri, Sobari, Tawwakal, 
2019). Studi kasus pada pemilihan gubernur di Jawa Timur 2018 tersebut menunjukkan bahwa kiai tidak lagi bersikap dominan tetapi lebih terbuka terhadap pilihan politik santrinya. Santri mulai mengenal sumber informasi selain kiai dan memiliki rational choice dalam menentukan sikapnya. Oleh sebab itu, kajian ini mengungkapkan bahwa pilihan politik santri tidak lagi dipengaruhi oleh hubungan patron-client. Pendapat lain mengatakan bahwa persaingan kekuatan kapital dari pengusaha-politisi telah mengalahkan kekuatan sosio-kultural kiai politisi. Praktik politik uang yang dilakukan oleh pengusaha-politisi telah berhasil menggeser kekuatan elektoral kiai dan merebut dukungan masyarakat yang semula berada di bawah otoritasnya (Zamroni, 2007).

Meskipun demikian, kuatnya pengaruh kiai dalam politik elektoral masih menjadi realitas yang dibuktikan oleh berbagai kajian. Chalik (2015) menggambarkan eksistensi kekuasaan dan ruang bermain para elit kiai yang mendominasi kekuatan politik pada pilkada serentak 2015 di Jawa Timur. Sebanyak 16 dari 19 paslon yang memenangkan pemilu adalah mereka yang memiliki dukungan kekuatan elit lokal berbasis pesantren. Realitas politik tersebut menunjukkan bahwa kemenangan para kandidat pilkada berkaitan 
erat dengan keterlibatan kelompok kiai yang mempermudah akses ke jaringan politik hingga level grassroot. Hasanudin (2017) menggunakan perspektif jaringan untuk membahas mobilisasi jaringan Hamida atau alumni pesantren Miftahul Huda pada pilkada 2011 dan 2016 di Tasikmalaya. Kemenangan paslon tertentu tidak selalu tergantung pada kekuatan parpol, tetapi ada kalanya tergantung pada kekuatan unsur pesantren, seperti tokoh kiai maupun jaringan sosial yang dibentuk oleh kiai.

Kajian Nurhadi dan Sunarso (2018) menemukan tiga bentuk peran kiai di pilkada Kabupaten Pamekasan 2018 yaitu sebagai patron politik, elit politik, dan mediator politik. Ketiga peran tersebut dilakukan kiai agar jamaah berpartisipasi dalam pemilu dan mendukung paslon tertentu sesuai arahannya. Studi lain mengungkapkan bahwa kiai merupakan opinion leader, mediator politik, dan vote getter (Assiddiq, 2020). Ketiga peran tersebut difokuskan sebagai strategi komunikasi politik dalam pemenangan paslon Jokowi-Ma'ruf di Jawa Timur. Kiai diposisikan sebagai aktor yang mampu melakukan counter isu sekaligus meraup dukungan massa. Studi yang diakukan Hidayat (2016) juga berhasil memetakan bentuk-bentuk peran kiai dalam pemilu, diantaranya kiai menggunakan agama untuk kepentingan politik, 
kiai sebagai fasilitator, kiai sebagai opinion leader, dan mobilisator massa. Selain itu, tulisan ini menampilkan proses konsolidasi antar elit pesantren serta antara elit pesantren dengan tim pemenangan resmi. Hanya saja, tidak ada pembahasan lebih jauh mengenai peran kiai sebagai konsolidator.

Studi terdahulu mengenai peran kiai cenderung tidak dikategorisasikan berdasarkan landasan tertentu sehingga memunculkan variasi peran yang beririsan satu sama lain. Misalnya, peran kiai sebagai mobilisator massa, opinion leader, dan kiai menggunakan agama untuk kepentingan politik sesungguhnya dapat dilakukan dalam waktu yang sama. Tulisan ini memetakan peran kiai berdasarkan level pengaruhnya, yakni pengaruh kiai di level elit akan berperan sebagai konsolidator dan pengaruhnya di level akar rumput akan berperan sebagai mobilisator massa. Selain itu, implikasi peran politik kiai terhadap perkembangan bisnis pesantren juga belum banyak dibahas. Kajian ini berusaha untuk menutup celah analisis yang ada dengan mengulas peran kiai sebagai konsolidator dan mobilisator serta menjelaskan implikasi kegiatan politik kiai terhadap perkembangan bisnisnya. 


\section{PENGARUH DAN PERAN KIAI DALAM POLITIK ELEKTORAL}

Merujuk pada pendapat Dhofier (1982), kiai merupakan gelar kehormatan yang diberikan masyarakat kepada seorang ahli agama Islam yang memiliki atau memimpin pesantren dan mengajar kitab-kitab klasik pada santrinya. Sosok kiai memang lebih umum dikenal sebagai pemimpin agama Islam sebelum ia terjun ke ranah politik praktis. Masalahnya, Islam tidak mengenal paham sekularisasi dan dalam sejarahnya, Rasulullah SAW merupakan pemimpin agama sekaligus pemimpin politik. Oleh sebab itu, istilah kiai politisi kemudian muncul untuk membedakan antara kiai yang terjun ke dunia politik dengan mereka yang hanya fokus mengurusi pendidikan di pesantren (Turmudi, 2004).

Kiai tradisional, yang sebagian besar bernaung di bawah NU, memiliki relasi yang kuat dengan ajaran Sunni. Para pemikir teologis Sunni lebih mengutamakan stabilitas politik dan keamanan, serta melarang memberontak terhadap penguasa. Prinsip ajaran Sunni adalah tawassuth (moderat), tawazun (seimbang), tasamuh (toleransi), dan i'tidal (tegak lurus). Prinsipprinsip tersebut membuat kiai Sunni lebih akomodatif terhadap pemerintah dan spektrum budaya apa pun (Ridwan, 2004). 
Di bidang politik, kuatnya pengaruh kiai berasal dari dua sumberdaya sebagai basis kekuasaannya. Pertama, hubungan kekerabatan dan intelektual. Relasi antar kiai atau antar pesantren diikat oleh genealogi sosial (kekerabatan) dan genealogi intelektual (rantai ilmu). Hubungan kekerabatan pesantren memainkan peranan dalam membentuk tingkah laku ekonomi dan politik, sehingga memperkuat pengaruh seorang kiai yang menjadi bagian dari relasi kekeluargaan tersebut. Semakin luas tali kekerabatan seorang kiai, maka semakin kuat pula pengaruh ekonomi dan politiknya. Pada bentuk relasi yang lain, genealogi intelektual, seorang kiai pada dasarnya mewakili watak pesantren dan gurunya di tempat ia belajar. Secara otomatis, dalam masalah politik pun, seorang kiai akan mengikuti langkah pesantren panutannya tersebut (Dhofier, 1982). Kedua, jabatan formal dalam parpol maupun organisasi NU. Jabatan formal ini merupakan basis pengaruh kiai terhadap individu lain yang berada di bawah struktur jabatannya. Sumber-sumber kekuasaan tersebut akan menguatkan pengaruh kiai karena seorang kiai yang bukan politisi dapat saja tidak diuntungkan secara elektoral dari sumber-sumber kekuasaan yang ia miliki. Secara praktik, sumberdaya tersebut berguna untuk melancarkan agenda politik elektoral. 
Peran kiai sebagai konsolidator dilakukan dengan memperkuat relasi politik antar kiai agar semua anggota kelompok memiliki satu pandangan atau tujuan (Chalik, 2018). Konsolidasi bertujuan untuk memastikan tidak ada kiai yang berbeda pilihan politik karena kemenangan kandidat ditentukan oleh upaya penguatan kekuatan politik (Hasanudin, 2017). Bentukbentuk upaya tersebut adalah diskusi, komunikasi, dan acara keagamaan yang bertujuan untuk menyatukan misi serta pandangan (Hidayat, 2016). Konsolidator jaringan kiai sering kali dilakukan oleh kiai yang paling berpengalaman di bidang politik atau bahkan yang paling berpengaruh di antara mereka, yakni yang instruksi dan anjurannya diikuti oleh kiai-kiai lain. Pengaruh salah seorang kiai sangat ditentukan oleh sumberdaya yang ia miliki. Sumber kekuasaan itulah yang digunakan oleh kiai untuk melakukan konsolidasi kelompoknya.

Di level akar rumput, mobilisasi suara pemilih diartikan sebagai penggerakan massa untuk mendukung dan memilih kandidat pemilu tertentu. Menurut Huntington dan Nelson (1994), ada dua bentuk partisipasi politik, yaitu dimobilisasi (mobilized participation) dan otonom (autonomous participation). Partisipasi jamaah atau kaum santri saat pemilu pada banyak studi merupakan partisipasi yang dimobilisasi 
oleh pemimpin agama atau kiai mereka. Mobilisasi suara jamaah akan efektif jika dilakukan oleh kiai (Nurhadi dan Sunarso, 2018) karena masyarakat yang masih kuat tradisi agamanya lebih mudah didekati dan digerakkan oleh tokoh agama atau elit politik yang berbasis pesantren (Chalik, 2015). Oleh sebab itu, masyarakat santri merupakan basis suara potensial dan kiai adalah kunci penguasaannya.

\section{PENGARUH KIAI PESANTREN DALAM PEMBENTUKAN SETTING SOSIAL POLITIK DI TEGALREJO}

Tegalrejo merupakan salah satu dari 21 kecamatan di Kabupaten Magelang. Kecamatan yang memiliki luas wilayah 35,89 $\mathrm{km}^{2}$ ini berbatasan dengan Kecamatan Candimulyo di sebelah selatan, Kota Magelang di sebelah barat, Kecamatan Grabag dan Kecamatan Secang sebelah utara, dan Kecamatan Pakis sebelah timur. Ada 21 Desa di Tegalrejo yaitu Tegalrejo, Banyuurip, Sidorejo, Sukorejo, Banyusari, Ngasem, Wonokerto, Ngadirejo, Tampingan, Soroyudan, Kebonagung, Dlimas, Girirejo, Dawung, Donorejo, Purwosari, Glagahombo, Purwodadi, Japan, Klopo, dan Mangunrejo. 
Gus Yusuf termasuk salah satu kiai yang turut memengaruhi kehidupan masyarakat terutama dalam pembentukan setting sosial politik di Tegalrejo. Gus Yusuf memiliki bisnis yang familiar di kalangan masyarakat, yaitu Radio Fast FM dengan program siarannya yang merakyat dan Rumah Sakit Umum Syubbanul Wathon yang mulai dibangun pada tahun 2018 dan diresmikan oleh Wapres Ma'ruf Amin pada tanggal 7 November 2019. Rumah sakit ini merupakan kemitraan antara Siloam Hospital (Lippo Group), PBNU, dan yayasan yang didirikan oleh keluarga Chudlori, yaitu Syubbanul Wathon. Yayasan Syubbanul Wathon memiliki porsi saham 40\%, PT. SILO memiliki 40\%, dan PBNU memiliki 20\% (Trianto, 2018). Selain bergerak di bidang kesehatan, yayasan yang diketuai oleh Gus Yusuf ini juga memiliki sekolah-sekolah setara TK hingga perguruan tinggi.

Gus Yusuf merupakan satu-satunya kiai API yang aktif berpolitik secara langsung untuk saat ini. Di awal karir politiknya, Gus Yusuf menjabat sebagai Ketua Dewan Pimpinan Anak Cabang (DPAC) PKB Tegalrejo kemudian sebagai Ketua Dewan Pimpinan Cabang (DPC) PKB Kabupaten Magelang dari tahun 1999 sampai 2007. Ketika terjadi konflik internal PKB antara kubu Gus Dur dengan Muhaimin Iskandar, Gus Yusuf sempat tidak 
memiliki jabatan struktural di partai ini. Pada tahun 2013, Gus Yusuf dipercaya DPP PKB untuk menjabat sebagai Ketua Dewan Pengurus Wilayah (DPW) PKB Jawa Tengah. Ia terpilih kembali untuk jabatan tersebut pada tahun 2018.

Pembentukan kekuatan PKB di Tegalrejo dilakukan oleh Gus Yusuf secara gradual sejak parpol tersebut berdiri. Suatu upaya yang tidak mudah mengajak kiai dan masyarakat untuk berpindah partai dari PPP yang ekslusif ke PKB yang terbuka. PKB sebagai partai yang tidak berlabel Islam membutuhkan penjelasan panjang agar diterima oleh kalangan NU. Gus Yusuf menganalogikan PKB sebagai kendaraan umum yang fokus mencari penumpang tanpa memandang identitas agar berhasil meraih banyak suara. Namun, PKB tidak lagi memerlukan label Islam karena sudah pasti isinya adalah orang-orang Islam fanatik. Pada awal berdirinya PKB, para kiai ada yang langsung berpindah partai tetapi ada juga yang membutuhkan waktu. Sisanya, sebagian kekuatan kiai di Tegalrejo tetap konsisten di PPP.

Tergerusnya kekuatan PPP membuat PKB menjadi suara mayoritas di kecamatan tersebut jika dilihat dari hasil Pileg 2019. Pada Pileg DPRD Kabupaten Magelang, PKB unggul dengan perolehan suara di Kecamatan Tegalrejo sebesar $26,83 \%$, unggul sebesar $28,15 \%$ untuk 
DPRD Jateng, dan unggul sebesar 29,46\% untuk DPR RI (KPU RI, 2019).

Terbentuknya setting sosial Tegalrejo sebagai basis NU sangat dipengaruhi oleh keberadaan pesantren. API yang didirikan oleh Kiai Chudlori merupakan pesantren terbesar dengan jumlah murid mencapai 13 ribu. Kiai Mudrik Chudlori dan Kiai Chanif Chudlori (kakak Gus Yusuf) merupakan pengasuh utama saat ini. Gus Yusuf bertindak sebagai representasi API di bidang politik dan hubungan kemasyarakatan seperti mengahadiri undangan pemerintah, partai politik, ormas, maupun masyarakat untuk mengisi pengajian. Selain API, berdasarkan data di Kantor Urusan Agama Kecamatan Tegalrejo, masih ada 21 pondok pesantren lainnya yang tersebar di desa-desa, antara lain Al-Hasyimi, Al-Munir, An-Najach, API Putri 2 Maqom, Asrama Pelajar Islam (API) Tegalrandu, Awwal I, Hidayatul Mubtadi-aat, Hidayatul Mubtadiin, Ianatul Mujtahidin, Miftahut Tholibin, Nurul Hasan, Subulurrosyad, Nurul Maghfiroh, Roudlotul Huda, Fatchul Ulum, Nurul Hidayah, API Beran, Wasilatul Huda, API ASRI, Darur Rahman, dan Awwal II. Namun, belum semua pesantren terdaftar di KUA Tegalrejo seperti Pesantren Dawung yang didirikan oleh Kiai Asmawi Abdul Aziz, Pesantren di Desa Kebonagung, Ponpes Tarbiyatun Nisa' (APIP 
I), dan lain-lain. Persebaran pesantren yang padat dan pengaruh kiai menjadikan warga muslim di Tegalrejo akrab dengan aktivitas-aktivitas keagamaan NU, seperti pengajian rutin, ziarah, tahlilan, yasinan, barjanji, dan sebagainya.

Hal yang menjadi catatan penting tentang setting sosial politik di Tegalrejo adalah penyatuan kekuatan kultur NU dan struktur PKB. Gus Yusuf berperan besar bagi pembentukan setting ini berkaitan dengan upayanya memobilisasi kekuatan NU untuk berpindah dari PPP ke PKB. Artinya, antara PKB dan NU Tegalrejo dari sisi elit maupun massa memiliki komposisi aktor yang sama atau paling tidak memiliki irisan yang besar (wawancara dengan mantan Ketua MWC NU Tegalrejo Ahmad Nasir, 25 Juli 2019). Sebagai contoh, dalam struktur MWC NU Tegalrejo, beberapa anggotanya merangkap jabatan dalam struktur PKB, seperti Kiai Showam, Ahmad Nasir, Kiai Tolhah, Kiai Ahmad Zaeni, Kiai Solihin, Muhammad Ma'mun, dan Miftahul Huda. Rangkap jabatan di lingkungan NU dengan parpol tertentu terutama PKB cenderung menjadi realitas yang umum meskipun ada larangan yang mengatur hal tersebut. Hal itu dikarenakan PKB sendiri sesungguhnya lahir dari rahim PBNU dan merupakan satu-satunya parpol yang diprakarsai secara resmi oleh PBNU. Dengan kata lain, 
MWC NU dan PKB ibarat koin mata uang, yakni MWC NU bergerak di bidang sosial-agama dan PKB bergerak di bidang politik, dengan motor penggerak aktor yang sama.

Dari sisi massa jamaah, sebagian besar muslim di Tegalrejo mengidentikkan diri sebagai warga NU secara kultural sekaligus simpatisan PKB dalam hal politik elektoral. Hal tersebut dibuktikan dengan kemenangan PKB di setiap pemilu legislatif dan terbentuknya Tegalrejo sebagai basis suara PKB. Dari 21 desa yang ada, setidaknya 17 darinya konsisten memenangkan suara legislatif PKB. PPP memiliki basis di Desa Sidorejo, Purwosari, dan Wonokerto. Berdasarkan hasil Pileg 2019, ketiga desa tersebut berhasil mengalahkan suara PKB dua kali dari tiga tingkat legislatif. Beberapa desa yang mengalahkan suara PKB hanya satu kali tidak dikategorikan sebagai basis. Desa-desa tersebut adalah Dawung, Japan, Kebonagung, dan Tegalrejo (KPU RI, 2019). Selain itu, ada satu desa merupakan basis Gerindra, yaitu Tampingan. PDIP memiliki suara kecil di kecamatan ini walaupun secara umum masuk kategori empat besar partai pemenang pileg. Dapat dikatakan bahwa hanya ada tiga parpol yang memiliki basis di Tegalrejo, yaitu PKB, PPP, dan Gerindra. Banyaknya desa yang menjadi basis PKB membuat kekuatan parpol 
ini memiliki posisi penting di setiap kontestasi pemilu. Perbandingan basis suara PKB dan PPP di Tegalrejo dapat dilihat dari hasil pileg 2019 berikut ini.

\section{Tabel 1. Suara PKB dan PPP pada Pileg 2019}

\begin{tabular}{|c|c|c|c|c|c|c|c|}
\hline \multirow{3}{*}{ No } & \multirow{3}{*}{ Desa } & \multicolumn{6}{|c|}{ PEROLEHAN SUARA } \\
\hline & & \multicolumn{3}{|c|}{$P K B$} & \multicolumn{3}{|c|}{$P P P$} \\
\hline & & $R I$ & Jateng & Magelang & $R I$ & Jateng & Magelang \\
\hline 1 & Banyusari & 191 & 188 & 177 & 126 & 60 & $12 O$ \\
\hline 2 & Banyuurip & 449 & 446 & 414 & 336 & 250 & 374 \\
\hline 3 & Dawung & 526 & 544 & 572 & 664 & 442 & 549 \\
\hline 4 & Dlimas & 950 & 917 & 858 & $62 O$ & 528 & 349 \\
\hline 5 & Donorojo & 347 & 381 & 3332 & 107 & 69 & 156 \\
\hline 6 & Girirejo & 659 & 658 & 524 & 137 & 115 & 67 \\
\hline 7 & Glagahombo & 362 & 318 & 341 & 79 & 56 & 67 \\
\hline 8 & Japan & 238 & 220 & 282 & 285 & 206 & 174 \\
\hline 9 & Kebonagung & 471 & 488 & 495 & 586 & 363 & 460 \\
\hline 10 & Klopo & 267 & 191 & 274 & 88 & 87 & 195 \\
\hline 11 & Mangunrejo & 290 & 288 & 302 & 151 & 244 & 197 \\
\hline 12 & Ngadirejo & 374 & 390 & 410 & 207 & 94 & 217 \\
\hline 13 & Ngasem & 112 & 91 & 83 & 21 & 24 & 14 \\
\hline 14 & Purwodadi & 536 & 47 & 635 & 43 & 54 & 22 \\
\hline 15 & Purwosari & 370 & 389 & 358 & 573 & 147 & 474 \\
\hline 16 & Sidorejo & 467 & 482 & 464 & 692 & 761 & 426 \\
\hline 17 & Soroyudan & 219 & 167 & 237 & 95 & 257 & 173 \\
\hline 18 & Sukorejo & 609 & 406 & 469 & 172 & 176 & 65 \\
\hline 19 & Tampingan & 577 & 609 & 396 & 85 & 68 & 64 \\
\hline
\end{tabular}




\begin{tabular}{|c|l|c|c|c|c|c|c|}
\hline 20 & Tegalrejo & 1013 & 715 & 927 & 562 & 929 & 404 \\
\hline 21 & Wonokerto & 187 & 187 & 161 & 274 & 213 & 230 \\
\hline \multicolumn{2}{|c|}{ Jumlah } & $\mathbf{9 2 1 4}$ & $\mathbf{8 1 2 2}$ & $\mathbf{1 1 7 1 1}$ & $\mathbf{5 9 0 3}$ & $\mathbf{5 1 4 3}$ & $\mathbf{4 7 9 7}$ \\
\hline
\end{tabular}

(Sumber: https://pemilu2019.kpu.go.id/)

\section{PERAN GUS YUSUF SEBAGAI}

\section{KONSOLIDATOR JARINGAN KIAI}

Peran Gus Yusuf sebagai konsolidator dilakukan dengan memperkuat jaringan kiai NU sebagai kekuatan elektoral. Jaringan kiai ini terdiri dari kiai dan tokoh MWC NU Tegalrejo sekaligus politisi maupun simpatisan PKB. Walaupun sebagian besar kiai politisi bergabung dalam MWC NU, bukan berarti organisasi ini terlibat politik praktis atau mendeklarasikan diri sebagai pendukung kontestan pemilu tertentu. Hanya saja, para anggotanya sebagai individu terlibat secara langsung dalam kegiatan politik di PKB. Dampaknya, beberapa kegiatan MWC NU dapat bersifat politis seperti pengajian rutin Ahad Pahing yang pada waktu tertentu digunakan sebagai sarana mobilisasi massa.

Identitas sebagai warga NU dan PKB perlu ditekankan karena tidak semua anggota MWC NU adalah politisi PKB dan tidak semua kiai tergabung dalam MWC NU. Misalnya, anggota Mustasyar MWC NU, Kiai Muslich 
adalah politisi PPP. Lain halnya dengan pengasuh Pesantren An-Najach, Kiai Mukti, ia memilih tidak bergabung dalam MWC NU meskipun ia termasuk kiai panggung yang terkenal. Secara praktik, MWC NU didominasi oleh aktor PKB mulai dari struktur, ide, hingga kegiatannya. Jaringan kiai yang dikonsolidasikan Gus Yusuf dapat dilihat pada gambar di bawah ini.

\section{Gambar 1. Jaringan Politik Gus Yusuf}

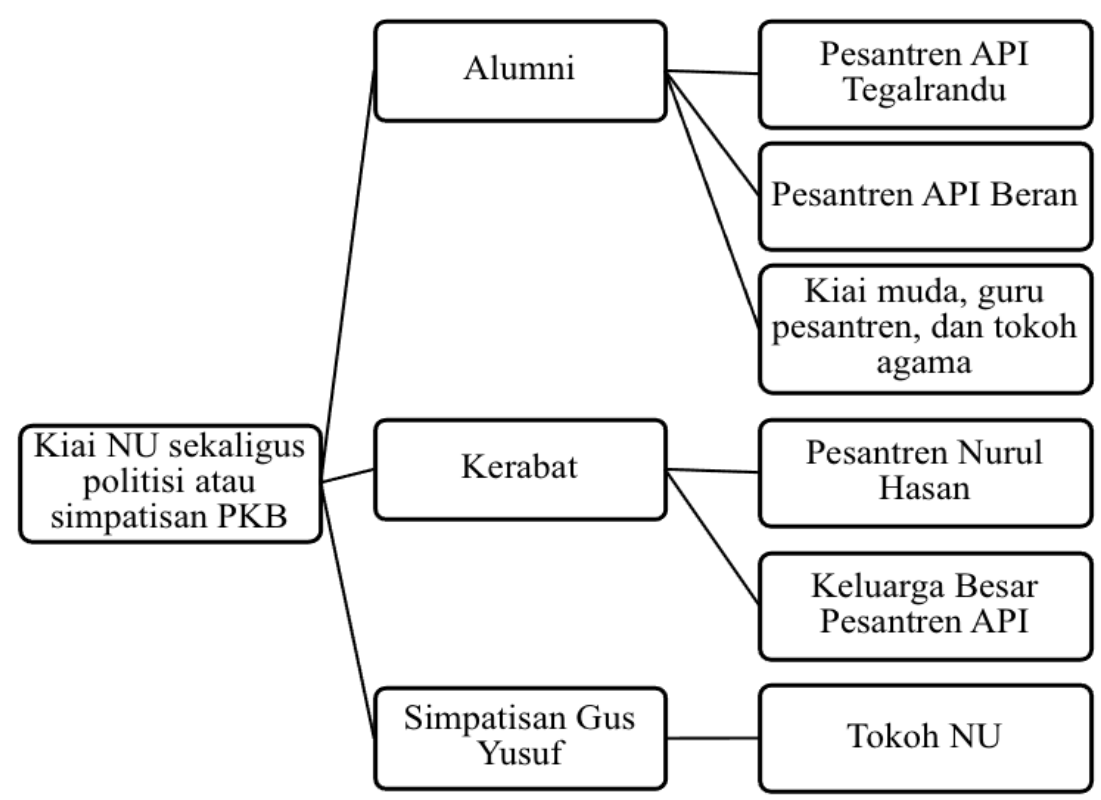

Pengaruh Gus Yusuf dalam jaringan kiai didukung oleh hubungan kekerabatan dan intelektual pesantren (Dhofier, 1982). Artinya, kerabat dan alumni API 
merupakan anggota jaringan kiai sekaligus sumber pengaruh Gus Yusuf. Khusus di Tegalrejo, sesuai batasan studi kasus, API memiliki relasi kekerabatan dengan Pesantren Nurul Hasan yang diasuh oleh Kiai Solikhun (Ketua Dewan Syuro PKB Kabupaten Magelang), Kiai Showam (Ketua DPC PKB Tegalrejo), dan Kiai Chamilin. Anak Kiai Solikhun sendiri, Gus Affan Mufti Hartoni, merupakan Ketua MWC NU Tegalrejo. Hubungan kekerabatan antara Gus Yusuf dengan Pesantren Nurul Hasan dapat dikatakan bersifat memperkuat pengaruh PKB di Tegalrejo. Apalagi sebagai kiai panggung, keuntungan tersendiri bagi kiai politisi, Kiai Showam dan Kiai Solikhun berperan aktif memobilisasi massa setiap kali pengajian.

Jika hubungan kekerabatan dengan Pesantren Nurul Hasan memperkuat dominasi PKB, maka hubungan kekerabatan sekeluarga Chudlori memperkuat dominasi mereka di lingkungan NU Tegalrejo. Keluarga Chudlori merupakan tokoh-tokoh yang menduduki jabatan strategis dalam struktur NU. Kiai Mudrik Chudlori duduk sebagai Mustasyar PCNU Kabupaten Magelang. Kiai Noor Machin Chudlori duduk sebagai Mustasyar MWC NU Tegalrejo. Keponakan Gus Yusuf, Kiai Achmad Izzuddin, memiliki jabatan sebagai Ketua PCNU Kabupaten Magelang. Keponakannya yang lain, 
Kiai Nashrul Arief, duduk sebagai Wakil Katib PCNU Jateng.

API juga memiliki hubungan intelektual dengan pesantren lain sebagai basis pengaruhnya. Secara otomatis, dalam masalah politik pun, seorang kiai akan mengikuti langkah dari gurunya. Sesuai namanya yaitu Asrama Perguruan Islam, API memang fokus untuk mencetak para guru dan kiai pesantren. Alumni API banyak dipercaya oleh kiai-kiai di wilayah Tegalrejo untuk mengajar di pesantrennya karena didukung oleh kualitas dan nama besar almamaternya. Hal itu membuat sebagian besar kiai muda dan guru pesantren di kecamatan ini merupakan alumni API (wawancara dengan Ahmad Nasir, 25 Juli 2019). Selain itu, ada dua pesantren salaf yang didirikan langsung oleh alumni API, yaitu Pesantren Asrama Pelajar Islam (API) Tegalrandu dan API Beran. Pesantren dan kiai alumni ini berfungsi sebagai rantai pengaruh API hingga ke dusun-dusun karena keputusan umum sebuah pesantren yang lebih kecil akan mengikuti arahan dari pesantren gurunya.

Menurut Gus Yusuf, konsolidasi struktur dan kultur kekuatan pesantren dan kekuatan NU merupakan strategi yang ia terapkan dalam pemenangan kandidat Jokowi-Ma'ruf di Jawa Tengah, termasuk di Tegalrejo. Para kiai lebih memilih forum-forum kultural informal 
sebagai media konsolidasi daripada pertemuan formal partai atau pun tim pemenangan. Proses konsolidasi jaringan kiai biasa dilakukan di rumah Gus Yusuf selesai pengajian Ahad Pahing yang mempertemukan banyak kiai MWC NU. Kosolidasi juga terkadang diadakan setelah atau pun sebelum pengajian Seninan (pengajian rutin Pesantren API setiap hari Senin). Tidak hanya kiai, kegiatan konsolidasi juga dihadiri oleh tokohtokoh agama karena kekuatan politik Gus Yusuf juga mengakomodir tokoh agama berpengaruh di lingkungan masyarakat (lihat gambar 1).

Kegiatan konsolidasi diisi dengan diskusi dan musyawarah untuk menghasilkan strategi pemenangan paslon 01 dan mobilisasi jamaah. Semangat solidaritas NU menjadi dorongan yang kuat bagi elit kiai di Tegalrejo karena ada unsur keterwakilan mereka di jabatan wakil presiden. Kesempatan ini disebut-sebut sebagai pengulangan sejarah pada masa Presiden Gus Dur. Sesuai dengan tradisi pesantren, kaum santri memiliki kewajiban mendukung perjuangan kiai. Motivasi lain yang didiskusikan para kiai adalah terjaminnya kepentingan NU jika Kiai Ma'ruf terpilih sebagai wakil presiden seperti pemberian dana resmi untuk pesantren, terwujudnya ketentraman beragama, kelestarian tradisi NU, peningkatan bantuan ekonomi 
pada masyarakat miskin, sekaligus peningkatan mutu pendidikan dan kesehatan. Harapan para kiai tentang adanya pemberian dana resmi pesantren muncul karena selama ini perkembangan pesantren bergantung pada dana amal yang diterima kiai. Sebagai lembaga pendidikan yang juga bertujuan mencetak generasi terpelajar di bidangnya, para kiai memandang bahwa mereka juga berhak mendapatkan dana dari pemerintah, seperti Bantuan Operasional Sekolah (BOS) pada sekolah formal. Setelah diskusi tertutup selesai, para kiai berbagi tugas untuk menyampaikan hal-hal yang telah didiskusikan kepada jamaahnya masing-masing melalui kegiatan kultural, seperti pengajian, yasinan, tahlilan, slametan, kenduri dan sebagainya (wawancara dengan Gus Yusuf, 4 Oktober 2019).

Konsolidasi jaringan kiai dalam beberapa studi kasus dilakukan secarainsidental tergantung padakepentingan dan pilihan politik saat itu. Tegalrejo menunjukkan realitas yang berbeda karena konsolidasi kekuatan politik dilakukan secara gradual dengan komposisi aktor yang stabil. Konsolidasi yang tidak instan tersebut dapat dilihat ketika Gus Yusuf membentuk dominasi PKB sejak parpol tersebut berdiri atau kepatuhan kiaikiai lain yang dimulai sejak kiai tersebut selesai berguru di API dan membangun pengaruhnya sendiri. 
Proses konsolidasi cenderung mudah dilakukan oleh Gus Yusuf karena ia memiliki keunggulan sumberdaya sebagai basis pengaruh. Dominasi kerabat Gus Yusuf dalam pos-pos jabatan PKB dan NU Tegalrejo membuat pengaruh keluarga Chudlori dalam jaringan kiai semakin kuat. Di sisi lain, jaringan intelektual berperan memperluas pengaruh API hingga ke dusundusun. Banyaknya kiai yang patuh pada Pesantren API berdampak pada semakin luasnya pengaruh Gus Yusuf.

Kekuatan kiai yang solid menjadi kunci kemenangan Jokowi-Ma'ruf di daerah basis pesantren tersebut. Paslon 01 memeroleh kemenangan tipis $51,7 \%$ di desa basis Gerindra-Tampingan, yang kebetulan tidak ada pesantrennya. Sedangkan di desa-desa lain, kiai terlihat memengaruhi perolehan suara. Desa Tegalrejo (tempat Gus Yusuf) menjadi penyumbang suara paslon o1 terbesar kedua sebanyak 2167 suara. Desa Sidorejo (tempat API Beran dan jamaah fanatiknya Pesantren API Tegalrejo) menjadi penyumbang suara tertinggi, yaitu 2288 suara. Sedangkan dari sisi persentase, Desa Sukerojo menjadi penyumbang suara Jokowi tertinggi, yakni sebesar $83,42 \%$ dengan total suara 1303 . Desa ini merupakan tempat bagi Pesantren API Tegalrandu berada. Berdasarkan perolehan suara tersebut, para kiai alumni API juga berperan besar dalam pemenangan 
Jokowi-Ma'ruf. Kiai-kiai tersebut bertugas menjangkau pengaruh Gus Yusuf dan PKB hingga level desa. Kiai di level desa merupakan bagian dari rantai pengaruh Gus Yusuf dengan masyarakat.

Hasil pilpres 2014 dan 2019 sebagai bahan perbandingan dapat dilihat dalam tabel berikut. Banyak desa seperti Dawung, Klopo, Tampingan, dan Wonokerto menunjukkan mobilisasi suara dari Prabowo-Hatta di pilpres 2014 ke Jokowi-Ma'ruf di pilpres 2019. Desadesa lain juga menunjukkan angka peningkatan suara Jokowi.

\section{Tabel 2. Hasil Pilpres 2014 dan 2019 di Kecamatan Tegalrejo}

\begin{tabular}{|c|l|c|c|c|c|}
\hline \multirow{2}{*}{ No } & \multirow{2}{*}{ Desa } & \multicolumn{2}{|c|}{ Pilpres 2014 } & \multicolumn{2}{c|}{ Pilpres 2019 } \\
\cline { 3 - 6 } & Jokowi - & $\begin{array}{c}\text { Prabowo - } \\
\text { Hatta }\end{array}$ & $\begin{array}{c}\text { Jokowi - } \\
\text { Ma'ruf }\end{array}$ & $\begin{array}{c}\text { Prabowo - } \\
\text { Sandi }\end{array}$ \\
\hline 1 & Banyusari & 567 & 351 & 702 & 308 \\
\hline 2 & Banyuurip & 1207 & 955 & 1692 & 664 \\
\hline 3 & Dawung & 654 & 1029 & 1088 & 717 \\
\hline 4 & Dlimas & 1043 & 796 & 1602 & 528 \\
\hline 5 & Donorojo & 406 & 403 & 613 & 298 \\
\hline 6 & Girirejo & 1163 & 857 & 1543 & 624 \\
\hline 7 & Glagahombo & 841 & 684 & 1164 & 596 \\
\hline 8 & Japan & 531 & 342 & 738 & 272 \\
\hline 9 & Kebonagung & 805 & 403 & 1144 & 303 \\
\hline 10 & Klopo & 541 & 630 & 826 & 483 \\
\hline
\end{tabular}




\begin{tabular}{|c|l|c|c|c|c|}
\hline 11 & Mangunrejo & 615 & 530 & 1053 & 311 \\
\hline 12 & Ngadirejo & 614 & 502 & 828 & 413 \\
\hline 13 & Ngasem & 478 & 316 & 686 & 184 \\
\hline 14 & Purwodadi & 621 & 426 & 842 & 294 \\
\hline 15 & Purwosari & 734 & 681 & 1220 & 371 \\
\hline 16 & Sidorejo & 1507 & 894 & 2288 & 490 \\
\hline 17 & Soroyudan & 1073 & 519 & 1288 & 409 \\
\hline 18 & Sukorejo & 993 & 441 & 1303 & 259 \\
\hline 19 & Tampingan & 912 & 1461 & 1362 & 1305 \\
\hline 20 & Tegalrejo & 3174 & 1293 & 2167 & 682 \\
\hline 21 & Wonokerto & 368 & 370 & 619 & 201 \\
\hline & Jumlah & 18847 & 13883 & 24768 & 9712 \\
\hline
\end{tabular}

(Sumber: https://pemilu2019.kpu.go.id/)

PPP juga menjadi topik penting ketika membicarakan kontestasi pemilu yang melibatkan warga NU. PPP berpindah dukungan dari pilpres 2014 yang mendukung Prabowo menjadi mendukung Jokowi pada pilpres 2019. Namun, basis PPP seperti Desa Sidorejo dan Purwosari, kecuali Desa Wonokerto yang memenangkan Prabowo dengan selisih dua suara, pada 2014 tetap memenangkan Jokowi-JK walaupun PPP pusat mendukung koalisi lawan. Hal tersebut dapat berarti kekuatan PPP belum cukup untuk mendongkrak suara Prabowo di pilpres 2014. Kemungkinan lain adalah para pemilih yang memenangkan PPP tidak serta merta mengikuti arahan parpol tersebut untuk mendukung Prabowo-Hatta, yang 
berarti suara PPP dengan suara Prabowo-Hatta tidak berbanding lurus.

Meskipun begitu, desa Dawung dan Klopo membuktikan kekuatan dukungan PPP pada paslonnya karena ada mobilisasi suara yang signifikan dari Prabowo-Hatta ke Jokowi-Ma'ruf. Mobilisasi suara tersebut dibaca sebagai kontribusi PPP karena masyarakat Dawung dan Klopo tetap memenangkan Prabowo-Hatta pada pilpres 2014 meskipun keduanya bukan merupakan unsur pesantren. Oleh sebab itu, basis NU PPP memiliki kontribusi terhadap peningkatan suara Jokowi pada Pilpres 2019 walaupun tidak sebesar PKB yang memiliki basis suara hampir di semua desa.

Selain PKB, Gerindra, PDIP, dan PPP, parpol lain memiliki suara yang relatif kecil. Dapat dikatakan bahwa basis suara cukup stabil mendukung Jokowi dari 2014 ke 2019 walaupun koalisi berubah. Hal tersebut berhubungan dengan kuatnya pengaruh Gus Yusuf dan PKB yang menjamin stabilitas kekuatan NU di Tegalrejo.

Berbeda sikap dengan PPP, Gerakan Pemuda Ka'bah (GPK) atau sayap pemuda PPP mendukung Prabowo pada pilpres 2019. Namun, efek dukungan GPK masih kalah dengan kekuatan kiai dan jumlah massa jamaah Islam tradisional yang mudah dimobilisasi. Hal tersebut 
dapat dilihat dari kenaikan suara Jokowi yang signifikan di Tegalrejo dan penurunan suara Prabowo walaupun mendapat dukungan dari mereka. Bahkan Komandan GPK Magelang, Gus Nurul, melakukan upaya konsolidasi GPK agar sejalan dengan sikap PPP pada pilpres 2019 (Amali, 2019).

Oleh karena itu, jika masih ada massa GPK yang mendukung Prabowo termasuk di Tegalrejo, maka jumlah mereka kurang signifikan. Begitu juga dengan sikap salah satu kiai di Tegalrejo yang mendukung Prabowo, yaitu Kiai Mukti, dinilai kurang membawa dampak berarti bagi perolehan suara paslon 02 di Tegalrejo. Sama dengan Pesantren API, Kiai Mukti juga memiliki pengajian rutin terbesar di Tegalrejo. Meskipun begitu, tampaknya ia tidak berhasil membawa kemenangan Prabowo di desanya, yaitu Dawung. Di desa tersebut, Jokowi unggul dengan perolehan suara 60,28\%. Angka tersebut masih terbilang baik karena melebihi 50\% walaupun rata-rata kemenangan JokowiMa'ruf di Tegalrejo sangat tinggi, yaitu 72\%.

Ada faktor penting yang memengaruhi kekalahan dukungan Kiai Mukti untuk Prabowo. Ia dikenal masyarakat sebagai kiai yang menjauhi aktivitas politik meskipun ia mendukung Prabowo-Sandi karena dikunjungi oleh cawapres 02 tersebut. Sebagai kiai yang 
kerap kali menegaskan bahwa kiai tidak seharusnya terjun ke dunia politik, maka aktivitas kampanyenya menjadi terhambat oleh prinsip tersebut. Ia tidak secara masif melakukan mobilisasi dukungan pada paslonnya seperti yang dilakukan kiai politisi lain, seperti Gus Yusuf, Kiai Showam, dan Kiai Solikhun.

Hal yang menarik dari konsolidasi tersebut adalah tidak adanya proses pembentukan koalisi baru atau koalisi yang tergantung pada kepentingan elektoral sesaat, seperti dalam kajian Chalik (2016) dan Hidayat (2016). Solidaritas jaringan kiai di Tegalrejo telah terbentuk jauh-jauh hari sebelum agenda pemilu dimulai. Anggota koalisi kiai ini cenderung stabil dari segi komposisi aktor, pemimpin, preferensi politik, hingga kepentingan. Hal itu bisa terjadi karena ada kiai yang paling berpengaruh di antara mereka sehingga dapat mengendalikan stabilitas jaringan yang telah terbentuk. Apalagi pola hubungan di pesantren yang bersifat patron-client dan keunggulan sumberdaya sebagai basis pengaruh seperti jaringan kekerabatan dan intelektual yang luas serta jabatan tinggi di PKB dan NU, membuat nasihat dan instruksi Gus Yusuf selalu dipatuhi oleh masyarakat santri (wawancara dengan Ahmad Nasir, 25 Juli 2019). Oleh sebab itu, proses konsolidasi menjelang Pilpres 2019 dapat diartikan 
sebagai konsolidasi lanjutan karena sesungguhnya kekuatan politik telah terbentuk sebelum kontestasi tersebut berlangsung.

\section{PERAN GUS YUSUF SEBAGAI MOBILISATOR SUARA PEMILIH}

Secara umum, peran Gus Yusuf sebagai mobilisator suara jamaah tidak berbeda dengan kiai-kiai lain, apalagi mereka sudah berdiskusi tentang isu-isu terkini menjelang pilpres. Namun, Gus Yusuf memiliki pengaruh terkuat pada massa PKB karena kedudukannya sebagai Ketua PKB Jateng. Gus Yusuf juga memiliki akses untuk menggerakkan massa melalui pengajian-pengajian rutin terbesar di Tegalrejo. Berbeda dengan kiai-kiai lain yang masih memiliki kesempatan untuk berkumpul dalam acara kultural dengan warganya, Gus Yusuf terkadang tidak memiliki kesempatan tersebut. Sebagai gantinya, ia selalu mengirimkan para santrinya untuk yasinan dan tahlilan di rumah-rumah penduduk sekitar pesantren. Oleh sebab itu, pengajian merupakan sarana utama bagi Gus Yusuf untuk menggerakkan massa pemilih.

Setidaknya, ada empat pengajian rutin yang digunakan Gus Yusuf sebagai sarana mobilisasi massa. Pertama Seninan, yaitu pengajian rutin pesantren 
API yang diadakan setiap hari Senin. Pengajian warisan kiai Chudlori ini bertempat di masjid Tegalrejo. Ada satu sampai dua kiai yang berceramah terlebih dahulu sebelum kiai API tampil sebagai pembicara. Pengajian ini dihadiri sekitar dua ribu jamaah dari Tegalrejo dan sekitarnya, serta jamaah dari wilayah Jawa Tengah. Seninan menjadi sarana mobilisasi yang efektif karena dilaksanakan setiap minggu dengan audiens yang relatif sama. Banyak warga Tegalrejo menjadikan Seninan sebagai rutinitas mereka sehingga setiap hari Senin mereka akan menghadiri pengajian ini.

Kedua, salah satu agenda MWC NU yaitu pengajian Ahad Pahing. Acara ini merupakan pengajian keliling warga NU yang diadakan dari satu desa ke desa lain di Tegalrejo setiap 35 hari sekali. Pengajian Ahad Pahing merupakan sarana relasi yang lebih dekat antara Gus Yusuf dengan masyarakat karena terjunnya kiai ke level desa dapat mempererat hubungan mereka. Ketiga, mujahadah Ahad Wage. Acara tersebut merupakan kegiatan rutin kader-kader PKB Tegalrejo. Audiens dari acara ini sebagian besar sama dengan pengajian Ahad Pahing karena massa PKB dan MWC NU relatif sama orangnya. Keempat, Pengajian Kliwonan yaitu pengajian pada malam Ahad Kliwon sebagai media relasi antara alumni dan kiai API. Gus Yusuf rutin 
mengisi dakwah di pengajian ini berkaitan dengan tugasnya sebagai representasi pesantren API. Acara yang diselenggarakan setiap 35 hari sekali ini juga dihadiri oleh para alumni asal Tegalrejo.

Melalui pengajian, Gus Yusuf mengaplikasikan beberapa metode untuk menggerakkan massa pemilih. Metode pertama yaitu penyampaian landasan teologis. Para kiai juga berperan penting membangun kesadaran demokrasi para jamaahnya dan tidak serta menjadikan mereka objek politik untuk mendukung paslon tertentu tanpa melandasinya dengan dalil-dalil yang sesuai. Kesadaran berdemokrasi para jamaah sengaja dibangun karena kiai memandang bahwa demokrasi merupakan sistem yang sesuai dengan ajaran Islam. Menurut fikih siyasah (politik), demokrasi hanyalah proses bukan tujuan. Gus Yusuf mengenalkan demokrasi kepada masyarakat sebagai musyawarah dan melandasinya dengan dalil-dalil yang ia pelajari di pesantren. Contohnya, perkataan Ali bin Abi Thalib, "al haqqu bila nidhamin yaghlibuhul bathilu bin nidham" atau "sesuatu kebenaran yang tidak tertata itu bisa terkalahkan oleh kebatilan yang lebih tertata”. Kalimat ini sangat familiar di kalangan NU yang berisi pesan agar warga NU selalu solid dan menyatukan orientasi demi kejayaan Islam. Dalam konteks politik elektoral, kalimat 
ini mengandung pesan agar warga NU merapatkan barisan mendukung pilihan politik kiai yang dianggap sebagai suatu tindakan kebenaran.

Gus Yusuf juga menyampaikan Atsar Umar bin Khatab, "innahu laa islama illa bil jamaah walajamaata illa bil imaroh wala imarota illa bit-toah", yaitu "tidak ada Islam kecuali berjamaah, tidak ada jamaah kecuali ada imamnya (pemimpin), dan tidak ada (gunanya) kepemimpinan kecuali tanpa ketaatan”. Penyampaian Atsar tersebut merupakan stimulus pada masyarakat agar bergerak ke kubu pemerintahan Jokowi karena maknanya sesuai dengan kebutuhan politik PKB. Umar bin Khattab dalam Atsarnya mengingatkan kaum muslimin agar menaati kebijakannya sebagai pemimpin dalam pemerintahan yang sah. Secara implisit, Gus Yusuf mengajak masyarakat untuk menaati Jokowi sebagai pemimpin dalam pemerintahan sehingga posisi Jokowi sebagai petahana dalam kasus ini membawa keuntungan.

Gus Yusuf juga menceritakan pada jamaah tentang Hadis Riwayat Abu Dawud yang berisi kewajiban memilih pemimpin. Perintah Rasullullah SAW jika ada sahabat yang keluar, yaitu "bila kamu berjalan bertiga, hendaklah kalian menjadikan salah seorang di antaramu sebagai pemimpin”. Berdasarkan dalil tersebut dan dalil 
lainnya, Gus Yusuf memerintahkan pada masyarakat untuk memilih pemimpin mulai dari kepala desa, bupati, gubernur, sampai presiden. Selain itu, untuk memastikan agar pemimpin tersebut tidak sewenangwenang, masyarakat harus memilih pengawas sebagai wakil rakyat, yaitu pemimpin legislatif. Khusus masalah Pilpres 2019, Gus Yusuf langsung menyebut nama Jokowi-Ma'ruf sebagai paslon yang seharusnya dipilih oleh masyarakat NU. Menurut para kiai di Tegalrejo, paslon ini dapat menjaga paham ahlussunnah dan keutuhan NKRI warisan para ulama.

Metode mobilisasi yang kedua yaitu membangun citra positif paslon 01 karena pada masa kampanye, kedua tim saling melempar isu yang melemahkan lawan. Beberapa isi dakwah Gus Yusuf masih sama dengan kampanye Pilpres 2014, yaitu menangkal seranganserangan yang dianggap sebagai fitnah contohnya bahwa Jokowi adalah keturunan Cina, beragama Kristen, dan berasal dari keluarga PKI (Maharani, 2014). Kiai Ma'ruf sendiri diceritakan memiliki semangat yang tinggi untuk memperjuangkan NU di usianya yang sudah tidak muda lagi. Paslon ini sesuai dengan kekuatan awal Indonesia, yaitu nasionalis-religius (orang-orang yang cinta tanah air tetapi juga berpegang teguh pada agamanya). Jokowi dipercaya dapat membangun infrastruktur 
dan ekonomi sedangkan Kiai Ma'ruf dapat mengurusi masalah moral dan pendidikan. Pada simpulannya, Gus Yusuf menyampaikan bahwa Jokowi-Ma'ruf merupakan pasangan yang ideal.

Metode ketiga yaitu menyerang lawan politik. Gus Yusuf menyampaikan agar NU harus menang dalam pilpres kali ini. Kalau tidak, maka kelompokkelompok yang berseberangan dengan NU akan menjadi pemimpin. Kiai dan masyarakat NU di Tegalrejo memiliki kewaspadaan terhadap kelompok yang mereka sebut sebagai Islam transnasional, khilafah, Islam garis keras atau radikal, walaupun penyebutan dan realitas tersebut merupakan perdebatan tersendiri. Para kiai khawatir jika kelompok yang dinilai anti NU ini menang pemilu, maka tradisi-tradisi keagamaan yang sudah dilaksanakan masyarakat Tegalrejo seperti yasinan, tahlilan, dan ziarah akan dilarang. Kalangan kiai memercayai bahwa kelompok-kelompok tersebut telah menumpang ke paslon 02 sehingga Gus Yusuf mengingatkan pada masyarakat agar memenangkan paslon Jokowi-Ma'ruf dan mengikuti ulama-ulama yang sudah mereka kenal di lingkungannya.

Pengangkatan isu kelompok anti NU ini efektif menimbulkan semangat masyarakat NU di Tegalrejo untuk memilih Jokowi-Ma'ruf. Bahkan, isu radikal 
bukan hanya menjadi dorongan namun juga ketakutan di masyarakat yang masih memegang teguh tradisi ahlussunnah. Kiai mampu memanfaatkan ketakutan tersebut sebagai penggerak masyarakat agar mendukung pilihan politiknya.

Berdasarkan peningkatan suara Jokowi dari 2014 ke 2019, dapat dibaca bahwa sesungguhnya ada harapan yang besar dari kalangan NU agar kelompoknya terwakili dalam jabatan politik yang tinggi. Hal tersebut dapat dilihat dari semangat mereka untuk menonjolkan peran, isu, dan kepentingan NU begitu ada kesempatan, yaitu majunya Kiai Ma'ruf sebagai cawapres. Gus Yusuf sendiri memberi penekanan pada terwakilinya kalangan NU dalam pemerintahan sehingga majunya Kiai Ma'ruf merupakan dorongan kuat bagi warga NU untuk mendukung paslon 01.

\section{MOTIF POLITIK KIAI:}

\section{ANTARA KEPENTINGAN NU DAN BISNIS}

Peran kiai dalam politik elektoral merupakan hal yang menarik untuk dibicarakan karena kontroversi dan yang beredar di kalangan mereka sendiri. Berdasarkan pemahaman masing-masing kiai, ada yang mengharamkan, membolehkan, bahkan mewajibkan 
para pemimpin agama untuk terjun ke dunia politik yang dianggap kotor. Meskipun begitu, terjunnya kiai ke dalam ranah yang dianggap kotor tersebut saat ini telah menjadi realitas yang umum. Politik berkaitan dengan keuntungan materi maupun kekuasaan yang dapat digunakan untuk mewujudkan kepentingan masingmasing. Kiai yang terjun ke dunia politik memiliki motif tersendiri yang membuatnya lepas dari kontroversi yang berkembang. Pembahasan ini menjadi relevan untuk menemukan alasan terjunnya kiai ke ranah politik.

Gus Yusuf sendiri menganggap politik merupakan alat perjuangan kiai di masa modern. Perjuangan yang ia maksud adalah kelestarian paham ahlussunnah dan NKRI warisan para ulama. Motif Gus Yusuf tersebut dapat dikonfirmasi melalui realitas bahwa ia menolak beberapa jabatan publik untuk saat ini, seperti menolak tawaran Megawati dan Jokowi untuk berpasangan dengan Ganjar pada Pilgub Jateng 2018 (wawancara dengan Kiai Showam, 24 Juli 2019) serta memutuskan untuk tidak mencalonkan diri sebagai anggota DPR RI walaupun peluang terpilihnya sangat besar. Gus Yusuf mengaku belum tertarik dengan jabatan politik karena misinya saat ini adalah membesarkan nama PKB sebagai kendaraan politik warga NU. 
Pada Pilgub Jateng 2018, Gus Yusuf memilih untuk melawan PDIP dan Ganjar Pranowo. PKB Jateng berkoalisi dengan Gerindra, PKS, dan PAN yang merupakan oposisi Jokowi di pemerintahan. Salah satu alasan kuat Gus Yusuf yaitu ketidaksetujuan kalangan pesantrenterhadapkebijakan Full Day School dari Ganjar di periode pertamanya. Kebijakan tersebut dinilai akan mematikan masa depan pendidikan bercorak pesantren, yaitu madrasah diniyah (pendidikan agama di luar sekolah). Pendidikan tersebut biasanya dilakukan di dusun-dusun setelah siswa pulang sekolah. Jika mereka belajar di sekolah sampai sore, maka mereka tidak akan memiliki waktu untuk belajar Al-Quran dan ilmu agama Islam.

Kebijakan Ganjar tersebut mendapat penolakan keras dari kalangan pesantren termasuk Gus Yusuf. Karena audiensi dengan Ganjar tidak membuahkan hasil, Gus Yusuf menyampaikan aspirasinya langsung pada Jokowi waktu berkunjung ke Pesantren API. Walaupun Jokowi berjanji akan menunda kebijakan Ganjar tersebut, namun janji tersebut tidak pernah terealisasi (Pertiwi, 2017). Oleh karena itu, Gus Yusuf dan PKB memilih untuk mengawal sendiri kepentingan pesantren dan NU dengan mengusung cagub dan cawagub yang sejalan dengan kepentingan tersebut. Namun, Sudirman-Ida 
mengalami kekalahan pada kontestasi Pilgub Jateng 2018. Keputusan Gus Yusuf untuk mencalonkan Ida Fauziyah, terlepas dari alasan yang lain, merupakan bentuk kesungguhannya dalam menjaga kepentingan NU.

Namun, bukan berarti Gus Yusuf tidak memeroleh keuntungan dari relasi yang terbangun dalam lingkaran politik Jokowi. Bersama Lippo Group dan PBNU, Yayasan Syubbanul Wathon semakin melebarkan usahanya dengan membangun rumah sakit di Tegalrejo. Pihak Lippo Group, terutama James Riady dikenal sebagai politisi sekaligus pembisnis yang dekat dengan pemerintahan Jokowi. Demikian juga dengan PBNU yang menyatakan dukungannya terhadap paslon 01 karena majunya Rais Aam PBNU sebagai pendamping Jokowi (Sasongko, 2018).

Berdirinya rumah sakit ini masih menuai pro dan kontra. Berbagai elemen masyarakat yang khawatir dengan isu Kristenisasi menolak unsur keterlibatan Siloam Hospital. Front Pembela Islam (FPI) dan berbagai unsur masyarakat pernah melakukan demonstrasi di area rumah sakit yang belum selesai dibangun. Mereka menuntut pembangunan dihentikan namun tidak dapat dipenuhi oleh pihak manajemen rumah sakit. Selain itu, masih banyak aspirasi masyarakat yang disampaikan 
langsung pada Gus Yusuf agar menghentikan kerja sama dengan Siloam Hospital karena alasan keagamaan.

Hal yang perlu digarisbawahi, tidak semua warga menentang pembangunan RSU Syubbanul Wathon, terutama mereka yang loyal pada Gus Yusuf. Namun, di daerah dengan penduduk mayoritas Islam ini, kerja sama antara Gus Yusuf dengan rumah sakit Kristen tetap menjadi fenomena yang mengejutkan. Selain mengadakan penolakan dengan berbagai media, masyarakat juga menyarankan atau paling tidak mempertanyakan tentang adanya opsi kerja sama dengan PKU Muhammadiyah.

Gus Yusuf pun berupaya menarik dukungan masyarakat yang kontra dengan menjelaskan alasan kerja samanya dengan Siloam Hospital. Gus Yusuf berpendirian bahwa ia mengutamakan kerja sama dengan rumah sakit yang sudah unggul dan mapan. Namun, alasan tersebut masih belum memuaskan masyarakat karena pada kenyataannya PKU Muhammadiyah juga merupakan rumah sakit swasta yang bereputasi baik. Gus Yusuf juga mengungkapkan bahwa kerja sama dengan pihak lain agama dapat memberikan peluang bagi mereka untuk masuk atau dekat dengan Islam. 
Terlepas dari alasan-alasan tersebut, sesungguhnya fenomena relasi NU atau paling tidak tokoh NU yang cenderung dekat dengan pihak Kristen daripada Muhammadiyah bukanlah hal yang baru sekaligus dapat dilacak rasionalisasinya. NU dan Muhammadiyah memiliki akar historis konflik yang berkepanjangan, baik konflik paham keagamaan maupun konflik politik.

Bukan rahasia lagi bahwa NU dan Muhammadiyah memiliki perbedaan paham terkait Islam yang sulit mereka kompromikan. Muhammadiyah lahir sebagai gerakan modernis-puritan yang diartikan sebagai upaya untuk memodernisasi Islam melalui jalan pemurnian (puritan) pemikiran dan praktik beragama. Agenda pemurnian tersebut dilakukan dengan pengembalian ajaran Islam pada Al Qur'an dan Hadis. Sebagai respons atas gerakan modernis-puritan, NU lahir dengan pondasi Islam tradisional yang berupaya untuk melestarikan pemikiran dan praktik keagamaan kalangan pesantren, seperti ajaran bermazhab dan tasawuf serta praktikpraktik keagamaan kalangan Islam di pedesaan seperti tahlilan, yasinan, barjanji, ziarah, dan masih banyak lagi. Pemikiran dan praktik kalangan NU ini kemudian menjadi sasaran kritik yang gencar dari pihak Muhammadiyah. Menurut pemikiran mereka, kalangan NU banyak mempraktikkan tradisi yang menjurus ke 
syirik dan bid'ah. Pemikiran NU dalam bermazhab juga dianggap oleh kalangan Muhammadiyah sebagai hal yang bertolak belakang dengan semangat kembali ke Qur'an dan Hadis sebagai pedoman umat Islam (Asy'ari, 2009).

Dari segi politik, Muhammadiyah dan NU juga berkompetisi dalam hal elektoral. Muhammadiyah dan NU bukanlah sayap partai dan tidak memiliki rantai struktural dengan parpol tertentu namun banyak dari mereka bergabung di parpol yang dianggap dekat dari segi kepentingan maupun pemikiran. Di era reformasi, kendaraan politik yang paling dekat dengan Muhammadiyah adalah PAN sedangkan NU adalah PKB (Asy'ari, 2009). Oleh karena itu, basis masing-masing organisasi menjadi penting bagi agenda politik parpol terkait.

Perebutan pengaruh dan jabatan antara NU dan Muhammadiyah sudah dimulai saat mereka tergabung dalam MIAI kemudian Masyumi. Dominasi kalangan modernis di tubuh Masyumi merupakan alasan utama bagi NU untuk keluar dari partai tersebut. Panggung politik Orde Baru juga menjadi hal yang paling mengecewakan bagi NU karena pos-posjabatan terutama dalam Departemen Agama-lagi-lagi didominasi oleh Muhammadiyah (Bruinessen, 1994). NU kemudian 
tersingkir dari pemerintahan Orba walaupun organisasi ini berperan besar dalam penumpasan PKI.

Berdasarkan pemaparan di atas, keputusan Gus Yusuf memilih Siloam Hospital sebagai mitra bisnisnya daripada PKU Muhammadiyah dapat dibaca sebagai upaya untuk mengamankan pengaruh NU di kalangan umat Islam dan meminimalisir potensi konflik. Muhammadiyah berpotensi menggerus basis NU di Tegalrejo dan sekitarnya. Hal tersebut sejalan dengan gerakan Muhammadiyah untuk memurnikan praktik keagamaan Islam yang kebanyakan dilakukan oleh umat Islam di pedesaan, terutama di basis NU seperti Tegalrejo. Padahal, basis NU juga penting untuk agenda politik elektoral. Jika ada ikon besar Muhammadiyah di suatu daerah NU, apalagi di bidang pelayanan kesehatan, maka nama dan pengaruh NU punya potensi luntur dari hati masyarakat. Pilihan berisiko tersebut tentu tidak diambil oleh Gus Yusuf. NU mengklaim banyak mengalami kekecewaan dan kerugian dalam beberapa konflik dengan Muhammadiyah. Oleh karena itu, dalam banyak kasus, kalangan NU lebih memilih bekerja sama dengan pihak Kristen daripada Muhammadiyah. Kecenderungan tersebut tidaklah memuaskan semua umat Islam. Terbukti bahwa Gus Yusuf banyak menerima protes dari masyarakat yang 
khawatir terhadap isu Kristenisasi. Pada level tersebut, Gus Yusuf dan para kiai dihadapkan pada tugas baru, yaitu memastikan stabilitas beragama semua pihak.

\section{KESIMPULAN}

Berdasarkan pembahasan mengenai dinamika sikap politik Gus Yusuf, dapat dikatakan bahwa Gus Yusuf memang mengawal kepentingan NU namun juga memeroleh keuntungan bisnis. Konsistensi Gus Yusuf pada kepentingan NU dilihat dari dinamika dukungan politiknya kepada pihak yang mengutamakan kepentingan tersebut. Masyarakat NU menganggap bahwa pemerintahan Jokowi memiliki kecenderungan untuk dekat dengan NU dan tegas terhadap kelompokkelompok yang dinilai anti NU. Tidak mengherankan jika Jokowi mendapat dukungan politik dari PBNU. Maka, bersama Lippo Group, Gus Yusuf dan PBNU membangun solidaritas politik yang akhirnya berbuah pada kesepakatan bisnis rumah sakit.

Dari segi elektoral, kemenangan paslon JokowiMa'ruf tidak dapat dilepaskan dari peran Gus Yusuf sebagai kiai-politisi paling berpengaruh di Tegalrejo. Pengaruh tersebut membuat Gus Yusuf memiliki akses leluasa untuk bergerak di ranah elit maupun grassroot. 
Peran Gus Yusuf sebagai konsolidator jaringan kiai berdampak signifikan terhadap perolehan suara karena jaringan ini berfungsi menjangkau massa pemilih secara merata. Jika Hasanudin (2017, p. 53) mengatakan bahwa kemenangan kandidat ditentukan oleh upaya penguatan kekuatan politik, maka studi kali ini membuktikan bahwa kelompok kiai yang solid atau kuat hubungannya akan menjadi kunci penguasaan kantong suara yang besar.

Gus Yusuf juga berperan efektif sebagai mobilisator massa karena ia memiliki akses ke pengajian-pengajian terbesar di Tegalrejo. Keberhasilan peran Gus Yusuf sebagai mobilisator massa juga didukung oleh penyampaian materi yang dapat menggerakkan massa NU. Berdasarkan temuan-temuan tersebut, tulisan ini menegaskan bahwa pemenangan kandidat JokowiMa'ruf di Tegalrejo menjadi efektif karena Gus Yusuf berperan kolaboratif sebagai konsolidator yang bergerak di level elit dan mobilisator yang bergerak di level akar rumput. 


\section{REFERENSI}

Alfirdaus, Lalila Kholid. (2013). Islam and Local Politics:

In the Quest of Kyai, Politics, and Development in Kebumen. Al-Jamiah, 2008-2010, 51 (2), 279-309.

Amali, Zaki. (2019, Februari 27). Bentrok GPK dan Kader PDIP Saat Massa PPP di Jateng Terbelah. Tirto. Diakses dari https://tirto.id/bentrok-gpk-dan-kaderpdip-saat-massa-ppp-di-jateng-terbelah-dhVn.

Arifin, Ichwan. (2008). Kiai dan Politik Studi Kasus Perilaku Politik Kiai dalam Konflik Partai Kebangkitan Bangsa (PKB) Pasca Muktamar II Semarang. Tesis. Universitas Diponegoro. Diakses dari http://eprints. undip.ac.id/17700/1/ICHWAN_ARIFIN.pdf. Semarang: Universitas Diponegoro.

Assiddiq, Dafis Ubaidillah. (2020). Menakar Peran Kiai dalam Pemilihan Presiden 2019 (Studi di Provinsi Jawa Timur). Journal of Governance Innovation, 2 (2), 191-208. Diakses dari http://ejournal.uniramalang. ac.id/index.php/JOGIV/article/view/505/387.

Asyari, Suaidi. (2010). Nalar Politik NU dan Muhammadiyah: Over Crossing Java Sentris. Yogyakarta: LkiS.

Bruinessen, Martin Van. (1994). NU Tradisi Relasi-relasi Kuasa Pencarian Wacana Baru. Yogyakarta: LKIS. 
Chalik, Abdul. (2015). Elit Lokal Berbasis Pesantren dalam Kontestasi Pemilihan Kepala Daerah di Jawa Timur. Jurnal Sosial dan Budaya Keislaman, 23 (2), 363381. Diakses dari http://ejournal.stainpamekasan.ac.id/ index.php/karsa/article/view/744/695.

Dhofier, Zamakhsyari. (1983). Tradisi Pesantren: Studi Tentang Pandangan Hidup Kyai. Jakarta: LP3ES.

Ernas, Saidin, Ferry Muhammadsyah Siregar. (2010). Dampak Keterlibatan Pesantren dalam Politik: Studi Kasus Pesantren di Yogyakarta. Kontekstualita, 25 (2), 194-224. Diakses dari https://media.neliti.com/ media/publications/37094-ID-dampak-keterlibatanpesantren-dalam-politik-studi-kasus-pesantren-diyogyakarta.pdf.

Febrina, Rasmi Hasfy, Bangun Udi Mustika, Adek Risma Dedees. (2014). Nahdlatul Ulama: Bebas untuk Oportunis? Menelisik Kontestasi Politik pada Pemilihan Kepala Daerah Kabupaten Banyumas Periode 2008 dan 2013. Jurnal Ilmu Sosial dan Ilmu Politik, 18 (2), 99-113. Diakses dari https://jurnal.ugm. ac.id/isp/article/view/13131/9360.

Geertz, Clifford. (1960). The Javanesse Kijaji: The Changing Role of Cultural Broker. Journal Comparative Studies in Society and History, 2 (2), 228-249. Diakses dari www.jstor.org. 
Gus Yusuf: Kiai Kecewa Tak Diajak Rembuk Soal Posisi Menag oleh Jokowi. (2019, Oktober 25). Kumparannews. Diakses dari https://kumparan.com/kumparannews/ gus-yusuf-kiai-kecewa-tak-diajak-rembuk-soal-posisimenag-oleh-jokowi-1s7TDLdCzwZ.

Hasanudin, Sansan. (2017). Mekanisme Religio-Politik Pesantren: Mobilisasi Jaringan Hamida dalam Politik Elektoral Tasikmalaya. Jurnal Sosiologi, 22 (1), 538o. Diakses dari http://journal.ui.ac.id/index.php/ mjs/article/view/6797/pdf.

Hidayat, Endik. (2016). Hubungan Kiai dan Politik: Peran Politik Kiai PadaPilpres 2014di PesantrenAreng-Areng Pasuruan Jawa Timur. Tesis. Diakses dari https://www. academia.edu/29778765/Hubungan Kiai dan Politik Peran Politik Kiai Pada Pilpres 2014 di Pesantren Areng- Areng Pasuruan Jawa Timur. Jakarta: Universitas Indonesia.

Hosnan, Mohammad. (2019). Pudarnya Kharisma Kiai dalam Kontestasi Politik Lokal di Madura. Jurnal Pemikiran dan Ilmu Keislaman, 2 (2), 308-327. Diakses dari http://jurnal.instika.ac.id/index.php/ jpik/article/view/119/75. 
Komisi Pemilihan Umum. (2020). Rekapitulasi Hasil Pemilu Presiden dan Wakil Presiden RI 2019. Diakses dari https://pemilu2019.kpu.go.id/\#/ppwp/ rekapitulasi/

Huntington,_Samuel dan Joan Nelson. (1994). Partisipasi Politik di Negara Berkembang. Jakarta: PT Rineka Cipta.

Maharani, Shinta. (2014, Juli 30). Kisah Gus Yusuf Melawan Fitnah Terhadap Jokowi. Koran Tempo. Diakses dari https://koran.tempo.co/read/347893/kisah-gusyusuf-melawan-fitnah-terhadap-jokowi?read=true.

Masruri, Wawan Sobari, George Towar Ikbal Tawwakal. (2019). Kyai-Santri Relationship in Electoral Politics: A Critical Point of View. Jurnal Ilmu Pemerintahan, 4 (2), 75-89. Diakses dari https://governmentjournal. org/index.php/jip/article/view/80/56.

Nurhadi dan Sunarso. (2018). Peran Kiai dalam Membangun Partisipasi pemilih. Jurnal Ilmiah Pendidikan Pancasila dan Keewarganegaraan, 3 (2), 169-175. Diakses dari http://journal2.um.ac.id/index.php/ jppk/article/view/7821/3750.

Patoni, Achmad. (2007). Peran Kiai Pesantren dalam Partai Politik. Yogyakarta: Pustaka Pelajar. 
Pertiwi. (2017, Agustus 8). Gus Yusuf: Pak Jokowi Bilang ke Saya akan Ditunda, Kok Jalan Terus. Detiknews. Diakses dari https://news.detik.com/berita-jawatengah/d-3591263/gus-yusuf-pak-jokowi-bilang-kesaya-akan-ditunda-kok-jalan-terus.

Ridwan. (2004). Paradigma Politik NU Relasi Sunni-NU dalam Pemikiran Politik. Yogyakarta: Pustaka Pelajar.

Sasongko. Joko Panji. (2018, Agustus 14). PBNU Siap Menangkan Jokowi-Ma'ruf Amin di Pilpres 2019. CNN Indonesia. Diakses dari https://www.cnnindonesia. com/nasional/20180814171857-32-322232/pbnu-siapmenangkan-jokowi-maruf-amin-di-pilpres-2019.

Trianto, Hery. (2018, Maret 20). NU-Lippo Bikin Usaha Patungan, Dirikan Rumah Sakit. Bisnis.com. Diakses dari https:// ekonomi.bisnis.com/read/20180320/12/752002/nu-lippobikin-usaha-patungan-dirikan-rumah-sakit.

Turmudi, Endang. (2004). Perselingkuhan Kiai dan Kekuasaan. Yogyakarta: LKiS.

Zamroni, Imam. (2007). Juragan, Kiai dan Politik di Madura. UNISIA, 30 (65), 264-276. Diakses dari https://journal.uii.ac.id/Unisia/article/view/2666. 